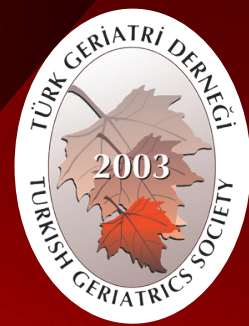

Turkish Journal of Geriatrics

DOI: 10.31086/tigeri.2019150574

2019;22 (1):66-73

- Ayşe ÇINAR ${ }^{1}$ iD

- Sulhattin ARSLAN ${ }^{2}$ (D)

- Yeltekin DEMIREL ${ }^{1}$ (D)

CORRESPONDANCE

Sulhattin ARSLAN

Cumhuriyet University, Faculty of Medicine,

Department of Chest Disease, Sivas, Turkey

Phone: 03462580213

e-mail: sulhattinaslan@mynet.com

Received: 06/06/2018

Accepted: 07/01/2019

Cumhuriyet University, Faculty

of Medicine, Department of family medicine,

Sivas, Turkey

2 Cumhuriyet University, Faculty of Medicine

Department of Chest Disease, Sivas, Turkey
RESEARCH

\section{THE RELATIONSHIP OF EXERCISE CAPACITY WITH FAT-FREE MASS AND BODY MASS INDEX IN ELDERLY PATIENTS WITH CHRONIC OBSTRUCTIVE PULMONARY DISEASE}

\section{Abstract}

Introduction: Skeletal muscle weakness is a major systemic manifestation of chronic obstructive pulmonary disease (COPD). Loss of muscle mass contributes to impaired exercise capacity and peripheral muscle weakness and manifests as reduced fat-free mass in patients with COPD. This study aimed to examine the effects of fat-free mass, body mass index and airway obstruction severity on exercise capacity.

Materials and Method: This study included 70 patients with COPD and 70 healthy individuals. Patients with COPD were divided into two groups: non-severe (GOLD Stage 1,2) and severe (GOLD Stage 2,3). Body mass index, fat-free mass, fat mass and percentage fat mass were measured, and pulmonary function tests were performed for all participants. The sixminute walk test was used as an index of exercise capacity. The Student's t-test, chi-square test and Pearson's correlation coefficient were used to compare study parameters.

Results: The average fat mass, percentage fat mass and six-minute walk test were reduced in the COPD cohort. No significant correlations were found between the six-minute walk test and body mass index, fat-free mass, fat mass and percentage fat mass. A significant correlation was found between the six-minute walk test and forced expiratory volume in one second (FEV1), forced vital capacity (FVC) and FEV1/FVC in patients with non-severe COPD.

Conclusion: Exercise capacity is significantly reduced in patients with COPD. The significant relationship between the six-minute walk test score and pulmonary function test variables indicates that disease-related obstruction affects exercise capacity.

Keywords: Exercise; Body mass index; Pulmonary Disease, Chronic Obstructive

ARAȘTIRMA

\section{KRONIK OBSTRÜKTIF AKCIĞER HASTALIĞI OLAN YAŞLI HASTALARDA EGZERSIZ KAPASITESININ BEDEN KÜTLE INDEKSI VE YAĞSIZ BEDEN KÜTLE INDEKSi ILE OLAN ILIŞKISI}

$\ddot{O}_{z}$

Giriș: İskelet kas güçsüzlüğü, KOAH'ın temel sistemik belirtilerinden birisidir. KOAH'da bozulmuş egzersiz kapasitesi ve periferal kas zayıflı̆ına belirgin olarak katkıda bulunan kas kütlesi kaybı, yağsız beden kütle indeksi (YBKi) azalma aracılığıyla gösterilebilir. KOAH'ı hastalarda YBKI ve beden kütle indeksi (BKi) ile hava yolu obstrüksiyon şiddetinin egzersiz kapasitesi üzerinde etkisini incelemektir

Gereç ve Yöntem: Çalışmamıza $70 \mathrm{KOAH}$ hastası ve 70 sağlıklı birey değerlendirmeye alınmıştır. KOAH ağır olmayan (GOLD Evre 1-2) ve ağır olan (GOLD Evre 2,3) olarak iki gruba ayrıldı. Hastaların BKI, YBKI, beden yağ kütlesi (BYK), BYK yüzdesi ölçüldü. Egzersiz kapasitelerini belirlemek için Altı dakika yürüme testi (6-DYT) yapıldı. Parametrelerin karşılaştırmalarında Student t testi, Ki-Kare testi ve Pearson korelasyon analizi kullanıldı. $\mathrm{p}<0.05$ ise anlamlı kabul edildi.

Bulgular: Çalışmamızda hastaların VYK ölçüm ortalaması, VYK yüzde düzeyi, 6 DYT düşük tespit edildi. 6-DYT ile BKI, YBKi, BYK ve BYK yüzdesi arasında anlamlı ilişki saptanmadı. Ağır olmayan KOAH grubunda 6-DYT ile FEV1, FVC yüzdesi ve FEV1/FVC arasında anlamlı ilişki saptandı.

Sonuç: 6-DYT testinin hasta grubunda daha düşük saptanması KOAH'lı hastalarda egzersiz kapasitesinin etkilendiğini göstermektedir. Ayrıca 6DYT ile solunum fonksiyon testleri arasındaki anlamlı ilişki bize egzersiz kapasitenin obstrüksiyondan etkilendiğini göstermektedir

Anahtar Sözcükler: Egzersiz; Beden kütle indeksi; Akciğer hastalığı, Kronik obstruktif 


\section{INTRODUCTION}

Chronic obstructive pulmonary disease (COPD) is a chronic disease characterised by progressive airway obstruction, which causes reduced exercise capacity and poor health-related quality of life. COPD is a systemic disease that is often accompanied by weight loss, decreased muscle mass, decreased functional capacity, anaemia and osteoporosis (1). In patients with COPD, malnutrition and subsequent reductions in protein synthesis lead to decreased fat mass (FM) and muscle mass, independent of pulmonary function. Malnutrition restricts exercise capacity by diminishing the force-generating capacity of skeletal muscles such as the diaphragm and other accessory respiratory muscles (2). Symptoms that reduce exercise capacity usually present during physical activities. Assessing exercise capacity is important for determining a patient's prognosis and creating and following an appropriate treatment plan. For this reason, exercise tests are used during pre- and post-treatment evaluations for patients with COPD and for determining physiological and subjective responses to exercise (3-4). The sixminute walk test (6-MWT) is widely used to assess exercise capacity in patients with COPD. The 6-MWT is safe, inexpensive and requires no special equipment. The general and combined responses of pulmonary, cardiovascular and muscular system components are assessed by the 6-MWT, which reflects functional exercise capacity during daily physical activities (5).

Pulmonary function test (PFT) impairments and exercise capacity restrictions are detected at varying severity levels in patients with COPD, depending on the disease duration and severity. Recent studies indicated that body mass index (BMI) was associated with mortality in patients with COPD (6).

The present study aimed to examine the effects of fat-free mass (FFM), BMI and airway obstruction severity on exercise capacity in elderly patients with COPD.

\section{MATERIALS AND METHOD}

This study included a total of 140 participants, including 70 patients diagnosed with COPD according to the Global Initiative for Chronic Obstructive Lung Disease (GOLD) 2014 criteria and 70 healthy controls.

Pulmonary function test and arterial blood gas (ABG) values were recorded for each participant. COPD severity was classified as one of four stages according to post-bronchodilator forced expiratory volume in one second (FEV1) based on GOLD 2014 criteria (7). Patients with GOLD stage 1 and 2 disease were classified as having non-severe COPD and those with GOLD stage 3 and 4 were classified as having severe COPD. All participants completed the 6-MWT to evaluate exercise capacity.

The next day, the height and weight of each participant was measured. Body weight was determined using a calibrated digital scale with a sensitivity of $0.1 \mathrm{~kg}$ before a meal and after removing shoes and outerwear. Height was measured using a metre stick with a sensitivity of $0.01 \mathrm{~m}$. The stick was fixed on the wall, and height was determined after the participant was instructed to remove his or her shoes (including accessories such as hair ties as appropriate) and stand with straight back and shoulders, looking straight ahead parallel to the floor with feet slightly apart and legs straight. Other variables of interest included BMI, FFM, FM and percentage fat mass (\%FM) measured with the TANITA body composition analyser (TBF-300, Tokyo, Japan). All measures were taken between 8 and $10 \mathrm{AM}$, following an overnight fast without intake of food or fluids and after defaecation. Participants were instructed to wear light clothing, and the measures were taken with bare feet and no shoes and socks. BMI was classified according to the World Health Organization criteria (8) as shown in Table 1, and percentage fat mass was classified as previously described (9) in Table 2.

\section{Statistical analysis}

Statistical analyses were performed using IBM SPSS Statistics 20 (IBM SPSS, Turkey) software. 
Apart from descriptive statistics (mean, standard deviation and frequency), the Student's t-test was used to compare normally-distributed, quantitative variables. The chi-square test and continuity (Yates) correction were used to compare qualitative variables. The Pearson's correlation coefficient was used to examine relationships between normallydistributed variables. $\mathrm{P}<0.05$ was considered to be statistically significant.

Table 1. Body Mass Index.

\begin{tabular}{|l|l|}
\hline BMI values $\left(\mathrm{kg} / \mathrm{m}^{2}\right)$ & Clasification \\
\hline Below $18.5 \mathrm{~kg} / \mathrm{m}^{2}$ & Weak \\
\hline Between $18.5-24.9 \mathrm{~kg} / \mathrm{m}^{2}$ & Normal weight \\
\hline Between $25-29.9 \mathrm{~kg} / \mathrm{m}^{2}$ & Overweight \\
\hline Between $30-34.9 \mathrm{~kg} / \mathrm{m}^{2}$ & 1.Grade obese \\
\hline Between $35-39.9 \mathrm{~kg} / \mathrm{m}^{2}$ & 2. Grade obese \\
\hline Over $40 \mathrm{~kg} / \mathrm{m}^{2}$ & 3.Grade morbit obese \\
\hline
\end{tabular}

BMI: Body weight $(\mathrm{kg}) /$ height $\left(\mathrm{m}^{2}\right)$

Table 2. Fat mass percentage.

\begin{tabular}{|l|r|r|}
\hline Classification & Male & Women \\
\hline 1-Underweight & $<8$ & $<15$ \\
\hline 2-Healthy & $8-15$ & $15-22$ \\
\hline 3-Slightly overweight & $16-20$ & $23-26$ \\
\hline 4-Overweight & $21-24$ & $27-32$ \\
\hline 5-Very overweight & $>25$ & $>32$ \\
\hline
\end{tabular}

\section{RESULTS}

This study included 140 participants 69 (49.3\%) males and 71 (50.7\%) females] with a mean age of $65.51 \pm 11.25$ years. Demographic characteristics of all participants are shown in Table 3.

All PFT sub-parameters, $A B G$ values $\left(\mathrm{PCO}_{2}, \mathrm{PO}_{2}\right.$ and $\mathrm{SO}_{2}$ ), body composition values (FM and \%FM) and the 6-MWT results were significantly lower in patients with COPD than in healthy controls (Table 4).
For patients with non-severe COPD, a positive and significant correlation was observed between the 6-MWT and weight $(p=0.026)$ (Table 5). Furthermore, a positive and significant correlation was observed between the 6-MWT and FEV1 $(p=0.002)$, FVC $(p=0.011)$ and FEV1/FVC $(p=0.048)$

For patients with severe COPD, a positive and significant correlation existed between the 6-MWT and FEV1 and FVC (Table 6). 
Table 3. Demographic characteristics of patients and control group.

\begin{tabular}{|c|c|c|c|}
\hline & Patient & Control & $p$ \\
\hline${ }^{1} \mathrm{Age}{ }_{\text {mean } \pm s d}$ & $65.51 \pm 11.25$ & $62.41 \pm 8.59$ & 0.071 \\
\hline \multicolumn{4}{|l|}{${ }^{2}$ Gender ${ }_{n, \%}$} \\
\hline Women & 27 (\%38.6) & $26(\% 37.1)$ & \multirow{2}{*}{0.074} \\
\hline Men & $43(\% 61.4)$ & $44(\% 62.7)$ & \\
\hline${ }^{1}$ Height ${ }_{\text {mean } \pm s d}$ & $163.27 \pm 9.67$ & $162.09 \pm 8.61$ & 0.445 \\
\hline${ }^{1}$ Weight $_{\text {mean } \pm s d}$ & $76.39 \pm 14.24$ & $80.16 \pm 13.1$ & 0.106 \\
\hline${ }^{1} \mathrm{BMI}\left(\mathrm{kg} / \mathrm{m}^{2}\right)_{\text {mean } \pm \mathrm{sd} \text { (median) }}$ & $28.79 \pm 5.66$ & $30.66 \pm 5.47$ & $0.048^{*}$ \\
\hline \multicolumn{4}{|l|}{${ }^{2} \mathrm{BMI}$ class ${ }_{\mathrm{n}, \%}$} \\
\hline Underweight & $1(\% 1.4)$ & $0(\% 0)$ & \multirow{6}{*}{0.338} \\
\hline Normal & $14(\% 20)$ & 9 (\%12.9) & \\
\hline Overweight & 27 (\%38.6) & 27 (\%38.6) & \\
\hline Obese class 1 & $19(\% 27.1)$ & 20 (\%28.6) & \\
\hline Obese class 2 & $8(\% 11.4)$ & 8 (\%11.4) & \\
\hline Morbid obese & 1 (\%1.4) & $6(\% 8.6)$ & \\
\hline
\end{tabular}

${ }^{1}$ Student $t$ Test ${ }^{2}$ Chi-Square Test ${ }^{*} p<0.05{ }^{* *} p<0.01$

Table 4. Evaluation of the ABG, PFT, Body Composition and 6 MWT results of the patients and control group.

\begin{tabular}{|c|c|c|c|}
\hline & $\begin{array}{r}\text { Patient } \\
\text { mean } \pm \text { sd }\end{array}$ & $\begin{array}{r}\text { Control } \\
\text { mean } \pm \text { sd }\end{array}$ & $\begin{array}{l}p \\
p\end{array}$ \\
\hline \multicolumn{4}{|c|}{ Pulmonary Function Test } \\
\hline${ }^{1}$ FEV1\% & $54.84 \pm 21.8$ & $101.16 \pm 15.92$ & 0.001 \\
\hline${ }^{1} \mathrm{FEV} 1 \mathrm{LT}$ & $1.37 \pm 0.63$ & $2.72 \pm 0.71$ & 0.001 \\
\hline${ }^{1} \mathrm{FVC} \%$ & $74.81 \pm 23.98$ & $106.36 \pm 16.21$ & 0.001 \\
\hline${ }^{1} \mathrm{FVC} \mathrm{LT}$ & $2.31 \pm 0.93$ & $3.45 \pm 0.94$ & 0.001 \\
\hline${ }^{1}$ FEV1/FVC & $57.94 \pm 10.12$ & $79.66 \pm 5.38$ & 0.001 \\
\hline \multicolumn{4}{|c|}{ Arterial Blood Gas } \\
\hline${ }^{1} \mathrm{pH}$ & $7.41 \pm 0.04$ & $7.4 \pm 0.03$ & 0.558 \\
\hline${ }^{1} \mathrm{PO}_{2}$ & $62.75 \pm 15.44$ & $79.38 \pm 5.89$ & 0.001 \\
\hline${ }^{1} \mathrm{PCO}_{2}$ & $36.96 \pm 7.99$ & $39.46 \pm 3.11$ & 0.017 \\
\hline${ }^{1} \mathrm{SO}_{2}$ & $90.01 \pm 8.5$ & $96.43 \pm 1.33$ & 0.001 \\
\hline${ }^{1} \mathrm{HCO}_{3}$ & $23.11 \pm 4.68$ & $23.6 \pm 1.84$ & 0.412 \\
\hline \multicolumn{4}{|c|}{ Body Composition and 6 MWT } \\
\hline${ }^{1} \mathrm{FFM}$ & $52.48 \pm 8.74$ & $52.27 \pm 8.76$ & 0.890 \\
\hline${ }^{1} \mathrm{FM}$ & $23.91 \pm 10.65$ & $27.89 \pm 10.71$ & 0.029 \\
\hline${ }^{1} \mathrm{FM}$ percentage & $30.28 \pm 10.26$ & $34.21 \pm 9.9$ & 0.023 \\
\hline${ }^{16} \mathrm{MWT}$ & $360.13 \pm 155.84$ & $560.09 \pm 113.49$ & 0.001 \\
\hline
\end{tabular}

${ }^{1}$ Student t Test 


\begin{tabular}{|c|c|c|c|c|}
\hline & \multicolumn{4}{|c|}{$6 \mathrm{MWT}$} \\
\hline & \multicolumn{2}{|c|}{ Non-severe COPD } & \multicolumn{2}{|c|}{ Severe COPD } \\
\hline & $\mathbf{r}$ & $p$ & $r$ & $p$ \\
\hline Weight & 0.347 & $0.026^{*}$ & 0.180 & 0.351 \\
\hline BMI & -0.301 & 0.056 & 0.012 & 0.951 \\
\hline FFM & 0.100 & 0.533 & 0.150 & 0.437 \\
\hline FM & -0.161 & 0.314 & 0.007 & 0.973 \\
\hline FM percentage & -0.129 & 0.422 & 0.004 & 0.986 \\
\hline
\end{tabular}

Pearson Correlation Analysis * $\mathrm{p}<0.05$

Table 6. Comparison of the $6 \mathrm{MWT}$ and PFT according to the degrees of severity of the patient group.

\begin{tabular}{lllll}
\hline & \multicolumn{3}{l}{6 MWT } & \multicolumn{2}{l}{ Severe COPD } \\
\cline { 2 - 4 } & \multicolumn{2}{l}{ Non-severe COPD } & $\mathrm{r}$ & $\mathrm{p}$ \\
\cline { 2 - 4 } & $\mathrm{r}$ & $\mathrm{p}$ & 0.457 & 0.013 \\
\hline FEV1\% & 0.274 & 0.083 & 0.515 & 0.004 \\
FEV1 LT & 0.470 & $0.002^{* *}$ & 0.540 & 0.003 \\
FVC \% & 0.200 & 0.209 & 0.583 & 0.001 \\
FVC LT & 0.399 & $0.011^{*}$ & 0.003 & 0.986 \\
FEV1/FVC & 0.305 & $0.048^{*}$ & & \\
\hline
\end{tabular}

Pearson Correlation Analysis

\section{DISCUSSION}

Dyspnoea, inadequate food intake due to difficulty in digesting food, malnutrition and excessive skeletal muscle apoptosis due to systemic inflammation are hallmark symptoms of COPD (10). With disease progression, these factors interfere with energy generation, and body weight is frequently reduced. Reductions in body weight are frequently accompanied by reduced skeletal muscle mass (10). In patients with COPD, exercise capacity is reduced due to increased airway resistance; decreased respiratory and peripheral muscle strength and impairment of lung mechanics, metabolic pathways, gas exchange and cardiac performance (11). Previous studies have indicated that exercise capacity is reduced in patients with COPD and that there is a positive correlation between $\mathrm{BMI}$ and exercise capacity (12). Casanova et al. noted that the 6-MWT distance is a better measure of mortality than FEV1 and BMI in patients with severe COPD (13). The relationship between the 6-MWT distance and mortality for patients with COPD was investigated by Cote et al. The authors have found that mortality significantly increased when the 6-MWT distance decreased below 350 m and have emphasised the prognostic significance 
of this distance (14). Savcl et al. found a correlation between the 6-MWT distance and BMI in patients with severe COPD (15). Bautista et al. compared functional lung capacity in 10 obese $(B M l \geq 35 \mathrm{~kg} /$ $\left.\mathrm{m}^{2}\right)$ and 10 non-obese $\left(21 \leq \mathrm{BMl} \leq 30 \mathrm{~kg} / \mathrm{m}^{2}\right)$ patients with COPD who exhibited similar airway limitations (16). At the end of the study, they found that the 6-MWT distance was significantly lower for obese patients with COPD (16). In another study, patients who were obese exhibited significantly higher functional lung capacities compared with those of individuals with normal weight. In the present study, a positive correlation was found between BMI and exercise capacity.

It has been stated that higher functional lung capacity is attributable to higher FFM (17). However, Gümüş et al. found no correlation between BMI and the 6-MWT (18). Sağlam et al. did not find a significant difference the 6-MWT between overweight and obese $\left(25 \leq \mathrm{BMI} \leq 34.9 \mathrm{~kg} / \mathrm{m}^{2}\right)$ patients with COPD and normal-weight patients $(18.5 \leq \mathrm{BMl} \leq 24.9 \mathrm{~kg} /$ $\mathrm{m}^{2}$ ) (10). In agreement with published findings, the findings of our study revealed that the 6-MWT distance was significantly lower in patients with COPD than in healthy controls. At the same time and in line with other studies, no correlation was observed between BMI and the 6-MWT.

It has been reported that underweight patients can exhibit decreased diaphragmatic muscle mass and thickness. A positive correlation has been found between FFM and respiratory muscle strength in patients with COPD (19). FFM is an important contributor to peripheral muscle strength. It is believed that more FFM protects respiratory muscle strength in overweight/obese patients with COPD (11). Deveci et al. found that FFM was significantly lower in patients with COPD than in controls and observed a positive correlation between FFM and the 6-MWT (20). A correlation was not found between the 6-MWT and FFM or FM in our study.

Patients with COPD typically experience increasingly severe airway obstruction and worsening of symptoms, such as dyspnoea and fatigue, as the disease progresses $(21,22)$. Chronic damage caused by COPD can ultimately affect activities of daily living (23). Uçar et al. found that the average 6-MWT distance was $384.71 \pm 73.27$ m (244-498 m), which had a positive but weak correlation with FEV1 and FEV1/FVC (24). In a study of 65 patients with COPD, Savcl et al. found a significant correlation between percent FEV1 and the 6-MWT only among patients with COPD and severe obstruction (15). In a study of 60 stable patients with COPD, Clarice et al. found that the 6-MWT distance showed a linear correlation with percent FVC, percent FEV and percent FEV1/FVC (25). Gümüs et al. found a positive correlation among FEV1, FVC and the 6-MWT (18). While investigating which PFT parameters best reflected maximal exercise capacity, Chlumsky et al. found that the total 6-MWT distance positively correlated with FEV1 and FEV1/FVC (25). In our study, a positive and significant correlation was found between the 6-MWT and FEV1 and FVC in patients with COPD; this finding is in agreement with literature.

The strength of this study is the significant relationship between the exercise capacity and PFT variables indicates that disease-related obstruction affects exercise capacity to a greater extent than body composition. The weakness of this study is the low number of cases.

In conclusion, exercise capacity is significantly reduced in patients with COPD. The significant relationship between the 6-MWT score and PFT variables indicates that disease-related obstruction affects exercise capacity to a greater extent than body composition. This shows us that we can protect exercise capacity by reducing the rate of PFT decline in elderly patients with COPD.

\section{Conflicts of interest}

The authors declare no conflict of interest in preparing this article 


\section{REFERENCES}

1. Prescott $\mathrm{E}$, Almdal T, Mikkelsen $\mathrm{KL}$, Tofteng CL, Vestbo $J$, Lange P. Prognostic value of weight change in chronic obstructive pulmonary disease: results from the Copenhagen City Heart Study. Eur Respir J 2002;20:539-544. (PMID:12358326).

2. Fitting JW. Nutritional support in chronic obstructive lung disease. Thorax 1992;47:141-3. (PMID:1519188).

3. Nici L. Mechanisms and measures of exrcise intolerance in chronic obstructive pulmonary disease. Clinics In Chest Medicine 2000;21(4):693704. (PMID:11194780)

4. Mujovic N, Mujovic N, Subotic D, et al. Preoperative pulmonary rehabilitation in patients with non small cell lung cancer and chronic obstructive pulmonary disease. Arch Med Sci 2014;10(1):68-75. (PMID:24701217).

5. ATS Committee on Proficiency Standards for Clinical Pulmonary Function Laboratories, ATS Statement: guidelines for thesix 6-minute walk test. Am J Respir Crit Care Med 2002;166:111-7. (PMID:12091180).

6. Gilberth EM, Weisman IM. Role of exercise stres testing in preoperative evaluation of patients for lung resection. Clinics In Chest Medicine 1994;15(2):389403. (PMID:8088100).

7. Maio S, Baldacci S, Martini F, et al. COPD management according to old and new GOLD guidelines: an observational study with Italian general practitioners. Curr Med Res Opin 2014 June;30(6):1033-42. (PMID:24450467)

8. Flegal KM, Carroll MD, Kit BK, Ogden CL. Prevalence of obesity and trends in the distribution of body mass index among US adults, 1999-2010. JAMA $2012 \mathrm{Feb}$ 1;307(5):491-7. (PMID:22253363).

9. Pekcan, G. Determination of Nutrition Status. Diet Handbook. In: Baysal A, Aksoy M (Eds). 5.th edition, Hatiboglu Publishing House, Ankara, Turkey, 2008 pp:67-143.

10. Saglam M, Savci S, Yagli NV, at al. Relationship between obesity and respiratory muscle strength, functional capacity and physical activity level in patients with chronic obstructive pulmonary disease, Turk J Physiother Rehabil 2013;24(3):157-62. (in Turkish).

11. Pepin V, Saey D, Laviolette L, Maltais F. Exercise capacity in chronic obstructive pulmonary disease: mechanisms of limitation. COPD 2007;4(3):195-204. (PMID:17729063)
12. Cote CG, Pinto-Plata V, Kasprzyk K, Dordelly LJ, Celli BR. The 6-min walk distance, peak oxygen uptake, and mortality in COPD. Chest 2007;132:1778-85. (PMID:17925409).

13. Casanova C, Cote CG, Marin JM, et al. The 6-min Walking Distance: Long-Term Follow Up in Patients with COPD. Eur Respir J 2007;29(3):535-40. (PMID:17107991).

14. Cote CG, Casanova C, Marın JM, et al. Validation and comparison of reference equations forthe 6-min walk distance test. Eur Respir J 2008;31:571-8. (PMID:17989117).

15. Savcı S, Ince Di, Arıkan H. Determinants of Six Minute Walk Test in COPD Patients With Moderate and Severe Airway Obstruction. Solunum Hastalıkları 2000;11:231-6. (in Turkish).

16. Bautista J, Ehsan M, Normandin E, Wallack RZ, Lahiri B. Physiologic responses during the six minute walk test in obese and nonobese COPD patients. Respir Med 2011;105:1189-94. (PMID:21414763).

17. Sabino PG, Silva BM, Brunetto AF. Nutritional status is related to fat-free mass, exercise capacity and inspiratory strength in severe chronic obstructive pulmonary disease patients. Clinics (Sao Paulo) 2010;65(6):599-605. (PMID:20613936).

18. Gümüş A, Kayhan S, Çınarka $H$, Yavuz A, Yüce S. Six Minute Walk Distance in Stable Chronic Obstructive Pulmonary Disease. J Clin Anal Med 2015;63: 274-7. (in Turkish).

19. Coşkun Ö, Uğurman F, Akkalyoncu B, Gözü A, Önde G, Samurkaşoğlu B. The Effect of Nutrition on the pulmonary functions in COPD. Solunum Hastalıkları, 2005;16: 153-60. (in Turkish).

20. Deveci F, Tuğ T, Turgut T, et al. Nutritional status, pulmonary functions and exercise performance in COPD cases. Tuberculosis and Thorax 2005;53:3309. (PMID:16456731).

21. Falter LB, Gignac MA, Cott C. Adaptation to disability in chronic obstructive pulmonary disease: neglected relationship to older adults, perceptions of independence. Disabil Rehabil 2003;25:795-806. (PMID:12959360).

22. Belza B, Steele BG, Hunziker J, Lakshminaryan S, Holt L, Buchner DM. Correlates of physical activity in chronic obstructive pulmonary disease. Nurs Res 2001;50:195-202. (PMID:11480528). 
23. Bestall JC, Paul EA, Garod R, Garnham R, Jones P, Wedzicha J. Usefullness of Medical Resaerch Council (MRC) dyspnea scale as a measure of disability in patients with chronic obstructive pulmonary disease. Thorax 1999;54:581-6. (PMID:10377201).

24. Uçar N, Akpınar S, Dursun AB, Alpar S, Kurt B. The Evaluation of Correlations Between Pulmonary Function Test, Carbon Monoxide Diffusion Capacıty and 6-Minute Walk Test in Chronic Obstructive Pulmonary Disease (COPD). Respiratory Diseases 2013;(24):1-4.

25. Chlumsky J, Sterbova L, Smolikova L. Relation between pulmonary ventilation parameters, exercise tolerance and quality of life in patients with chronic obstructive lung disease. VnitrLek 2002;48:320-32. (PMID:12061182). 